\title{
Function Shifts and Composition Form Reconstruction of Pakarena Dance
}

\author{
Fawziah Magfirah $Z^{1^{*}}$ Rumiwiharsih ${ }^{1^{* *}}$ Widya Rizky Ananda ${ }^{1 * * *}$ \\ ${ }^{1}$ Yogyakarta State University, Yogyakarta, Indonesia \\ ${ }^{*}$ Corresponding author. Email: fawzianmaghfiran@gmail.com \\ ${ }^{* *}$ Corresponding author.Email: rumiwiharsih@uny.ac.id \\ ${ }^{* * *}$ Corresponding author. Email: Widyarizkyananda@gmail.com
}

\begin{abstract}
This research discusses the transformation of the Pakarena Dance in the postmodern era. The dance has experienced social and cultural change and is now known as the Pakarena Anida Dance. Pitirim Sorokin explains the social cultural cycle into ideational, sensate and idealogic that is in line with the development of the Pakarena Dance. This study uses qualitative approach with case study research design. The data collection technique involves observations, interviews, documentation, and literature studies. Pakarena Dance experiences a shift in function from a ritual dance to a performance dance. The reconstruction of the composition form only takes place in the outer structure such as the movement types and specifications, accompanying music, number of dancers, floor patterns, fan position, and duration of the dance, whereas the core structure such as the cultural values and local wisdom is not affected. The Pakarena Anida dance is popular among students in South Sulawesi as it is one of the traditional dances taught in the Arts and Culture subject in high school, as well as in various dance studios and communities in the Pinrang regency.
\end{abstract}

Keywords—Function Shift, Pakarena Dance, Reconstruction, Pakarena Anida Dance

\section{INTRODUCTION}

Culture is a reflection of the diversity in Indonesia. The development of national culture requires the ability to preserve the values of regional cultures. Emblazoned on the concept of Bhinneka Tunggal Ika (Unity in Diversity), various types of traditional arts shape the Indonesian culture. Art is very closely related to human life. Ben Suharto states that art is not independent, but it is very close to local customs, community culture, and the beliefs of the community supporting it [1]. Therefore, the development of performance arts is more or less influenced by the development and change of civilization in society.

Performance arts experience ups and downs caused by various reasons, including changes in political and economic fields, changes in tastes of the audience/community, and its inability to compete with other forms [2]. Likewise, changes in governmental order influenced the kingdoms in South Sulawesi, especially the kingdom of Gowa, for the realization of the Unitary State of the Republic of Indonesia.

Dance is an expression of the human soul in the form of aesthetics: its existence is seen dependently, just like Pakarena Dance. Textually, dance is understood through its movements and techniques, usually called compositions.
Meanwhile, seen contextually in its relation to sociology or anthropology, dance is an inherent and integral part of the socio-cultural dynamics of society [3]. Pakarena Dance from the Makassar tribe of South Sulawesi cannot be separated from the culture of the surrounding community. Pitirim Sorokin's theory of sociocultural change cycle explains the interrelationships of various social phenomena. The variations of social indication are influenced by social structure and social processes. Pitirim Sorokin [4] divides culture into three types: ideational, sensate, and idealistic.

The Pakarena Dance was formerly known as Sere Jaga. Sere Jaga was a ritual ceremony that served as a complement to the coronation ceremony of the king, the cleansing of the royal heirloom, and the life cycle ceremony of the king and his family [5]. Sere Jaga means alert or aware (do not sleep all night). Since Islam becomes a religion in Makassar society, there has been a transition from the old beliefs of animism and dynamism to Islamic belief with its strict teachings about the oneness of God, a major step towards spiritual change. It also affected the religious rituals, especially Sere Jaga, which then changed its name and function into Pakarena or Akkarena which means play or player. Pakarena was danced all night from dusk until dawn, accompanied by the beat of drums. Pakarena is a traditional dance that first 
performed when Sultan Hasanuddin served as King of Gowa XVI. The Pakarena Dance was preserved from generation to generation by the King's consort, starting from Sultan Hasanuddin's mother to the next generation of royal members. [6] Royal guests of Gowa were often entertained with this dance. In ancient times, Pakarena could only be enjoyed by the royalty and their guests.

Many factors influence the development of human civilization and impact the cultural patterns of its people. Sumaryono states that the life of ethnic dances in their development is not solely intended and involved in their social and ritual functions in the middle of their communal society; they are also developed and transformed by artists into performance art for purposes outside of their social and ritual functions. Ethnic dances are packaged into entertaining arts, performances, or individual expressions that emphasize artistic and attractive considerations [7].

Artistic and attractive considerations of traditional arts provided a strong foundation for Andi Nurhani Sapada to initiate the formation of Ikatan Kesenian Sulawesi (Sulawesi Arts Association or $I K S$ ) as the beginning of cultural enlightenment in South Sulawesi. Ikatan Kesenian Sulawesi's effort to preserve Pakarena Dance in the 1950s was by reconstructing the structure and function of Pakarena Dance so that it could be more easily learned. These changes did not alter its characteristics. It also underwent a long process. Pakarena Dance underwent a shift in function, from a private ritual dance for Gowa Kingdom into a performance dance that can be enjoyed by all groups of people regardless of caste.

\section{METHOD}

This article on the function shift and composition form reconstruction of Pakarena Dance was written with a qualitative approach. It used case study research design to correlate the findings by the author with the results of other studies. Data collection techniques involved literature studies, documentation, and interviews. The literature studies used books and journals related to Pakarena Dance and Pakarena Anida Dance. Documentation obtained was from manuscripts and documents of classic Pakarena Dance as a ritual dance and Pakarena Dance as a performance dance. Interviews were conducted with Halilintar Latief (Cultural Practitioner of South Sulawesi and Lecturer of FSD UNM), Idha Elbara (South Sulawesi Dance Artist and Lecturer of FSD UNM), and Suriati (Cultural and Arts Teacher of SMAN 5 Pinrang). Data analysis techniques used were interactive cycles. The process of data analysis consisted of data collection, data presentation, data reduction, and conclusions. The data analysis was carried out in Gowa Regency and Pinrang Regency in South Sulawesi. The objects studied were the function of Pakarena Dance and the composition forms of traditional Pakarena Dance and Pakarena Anida Dance.

\section{RESULTS AND DISCUSSION}

Traditional Pakarena Dance developed among the Makassar Tribe community, especially the people in Gowa Regency, South Sulawesi, has now been known by all people of South Sulawesi, even Indonesian people, through the Pakarena Anida Dance by the maestro of South Sulawesi dances, Andi Nurhani Sapada. Changes in traditional culture that have occurred a lot resulted in many pros and cons views on this phenomenon.

Pitirim Sorokin divides the cycle of social and cultural changes into three types: ideational, sensate, and idealistic. First, the ideational culture in Pakarena Dance was the belief of the Makassar Tribe community on the existence of deity so that a ritual of worshiping a deity was called Sere Jaga, now known as Pakarena. Secondly, the sensate culture in Pakarena Dance is when Islam became the religion of the Makassar tribe: the Pakarena Dance was no longer a worship ritual but an obligatory dance held at the coronation ceremony of King Gowa and other royal events. Third, idealistic culture in Pakarena Dance is when it transformed into Pakarena Anida Dance without altering its ancestral cultural values: there is a compromise towards the culture developing in today's society.

This fusion of ideational and sensate is called the idealistic culture that is now developing in all of the traditional dances in the archipelago. The explanation about the process of the change in composition forms of Pakarena Dance resulting in the shift of its function, from ritual to performance, will be discussed in more details below.

\subsection{The Function Shift of Pakarena Dance}

Pakarena Dance is a traditional dance that first performed when Sultan Hasanuddin served as the King of Gowa XVI. Pakarena dance has been preserved from generation to generation by the King's consort starting from Sultan Hasanuddin's mother to the next generations of other royal members. Wiwik explained that this dance was formerly known as Sere Jaga, a sacred ritual that involved the old belief of the Makassar Tribe, called Sumanga, a belief in the God of Seuwae, the only one God [8]. The transition of the spirituality of the Makassar Tribe from animism and dynamism beliefs into Islamic beliefs changed Pakarena Dance. Pakarena Dance which was formerly held for the ritual worship of a God turned into a complementary dance at the coronation ceremony of the king and other Gowa Kingdom royal events.

In 1951, a group of art and culture enthusiasts was formed. This organization called "Organisasi Seni dan Budaya Mangkasara" (OSBM) or "Mangkasara Arts and Culture Organization" under the leadership of Fachruddin Daeng Romo, M. Mappaselleng Daeng Maggau, Andi Siti Nurhani Sapada, and Abdul Majid Daeng Siala tried to 
reconstruct the Traditional Pakarena Dance that had been so glorious several centuries before. Andi Nurhani Sapada intentionally created Pakarena Anida Dance as an act of retaliation against the government culture politics. The government necessitated the re-creation of regional cultures, which would then be performed at a stage. According to Halilintar Latief (January 2019), Pakarena was originally a dance that represented one ethnic identity. Then in the time of Soekarno, Pakarena was used as national interest in creating national culture. In addition to OSBM, there was another organization that promoted the culture of South Sulawesi to its glory; it was IKS (Ikatan Kesenian Sulawesi or Sulawesi Arts Association) in 1962. IKS offered art education to Indonesian children to get better acquainted to four ethnic dances (Makassar, Bugis, Mandar and Toraja) from South Sulawesi.

The Sulawesi Arts Association's (IKS) effort in preserving Pakarena Dance in 1960s was by reconstructing the structure and function of Pakarena Dance so that it could be more easily learned. These changes did not alter the dance's characteristics. It also underwent a long process. There was a shift in function of Pakarena Dance which was once used as a private ritual dance for the Kingdom of Gowa into a performance dance that could be enjoyed by all groups of people regardless of caste. Artistic and attractive considerations of a traditional art provided a strong foundation for Andi Nurhani Sapada to initiate the creation of Pakarena Anida Dance as a prelude to cultural enlightenment in South Sulawesi.

Innovation is a renewal, change, or introduction to new and better ways. Developing traditional performing arts means increasing the volume of its composition and expanding its area of recognition. Jamilah revealed [9] in 1962, for the first time Pakarena Dance was performed with 24 dancers at the Asean Games in Jakarta. At the time, the dance was patent and there were no fundamental changes. Floor pattern may continue to vary and dance techniques constantly improve, but officially, Pakarena Anida Dance already has a clear pattern.

The shift in function mentioned is a change in the mindset of the community. It can be seen from the initial function of the Pakarena Dance as a ritual dance of God/Deity worship to a performance dance. Soekanto stated that since prehistoric age, Indonesian culture has always experienced transition. The causing factors of social and cultural changes that originate from within the community are the increase and decrease in population, new discoveries, community opposition, and the uprising. While the causing factors of social and cultural changes from outside of the community are physical natural environment and influences of other cultures [10].

Soedarsono divided the functions of dance in a community into three: 1) Ceremonial Dance, as a medium of worship of a higher power with the aim of obtaining protection and safety; 2) Entertainment Dance, as entertainment to bring joys to the audience; 3) Performance Dance, this type of dance is performed in a special place, either on an open or closed stage, modern or traditional stage. The executants should pay attentions to dance moves, floor design, lighting, music, dynamics, themes, make-up and clothing, property, and event preparation with all its aspects [11].

Pakarena Dance in South Sulawesi has now been converted into a performance dance called Pakarena Anida Dance. This is emphasized by the research results by Anggrawansyah Syaharuddin [12] who explained that the function of Pakarena Dance underwent a significant change, from a sacred offering dance to a dance undergoing a sacred function change. It was later adapted into a profane function, when adapted to Pakarena Dance following the changing of times. This gives the positive impact that Pakarena Dance is not altered by the novelty of the times and is still known by the public as a form of preservation.

The marketing effect of tapes containing four ethnic dances (Makassar, Bugis, Mandar, and Toraja) published by $I K S$ to almost all Culture and Arts teachers in South Sulawesi has resulted in Andi Nurhani Sapada's Pakarena Anida Dance being very popular among students. Pakarena Anida Dance was a regular dance at annual competitions from Regency to Provincial Level in South Sulawesi. Students aged 9 to 18 get Pakarena Anida Dance lessons at school, making it the most popular dance among students. Pakarena Anida Dance performances are often found in competitions and as art performance in community events such as weddings, aqiqah and the welcoming of guests of honor.

\subsection{The Reconstruction of Pakarena Dance Composition Forms}

Artists, arts, and society are in a unified supporting relationship. Janet Wolf states that the development of art is related to the supporting community. Thus, Janet Wolf clearly explains that art as a social product [13]. Therefore, it is crucial for artists to pay attention to their audience. It is no longer possible to find a homogeneous society today; they tend to be heterogeneous based on different cultural, political, and religious backgrounds. The relationship between artists and heterogeneous societies is both a challenge and a consideration in the creation of art. Artists who are able to observe situations and conditions will be able to create works that attract attention.

Social change stated by Robert H. Lauer [14], is defined as an essential transformation of social structure meaning patterns of behavior and social interaction through normative expressions, values, and cultural phenomena. Benny H. Hoed [15] explains that there are three main 
characteristics of the single-total structure, transforming and being capable of managing themselves. Basically, Pakarena Dance is a structural construction which transforms to control culture.

The reconstruction application of traditional dances that adapt to the current era is connected by the creative actions of artists as a way to launch interesting innovations. It has positive and negative consequences. This means that on the one hand, if Pakarena Dance changes, there will be fears of losing the cultural identity of the original Makassar Tribe. However, on the other hand, through the transformation movement, Pakarena Dance gets extra value in the attention of the community to preserve it, especially the younger generation who are actively practicing regional dances. Without ongoing maintenance, there is no doubt that Pakarena Dance will meet its extinction.

The birth of postmodernism means the return of tradition in the form of a new position and context [16]. The statement can be understood that the return of traditional art in the text and context, as well as a new appearance that tends to adapt to the current situation. Transformation is a change in the temporary surface structure, not in the inner structure. The surface structure referred by Levi-Strauss is a physical structure, in this case the composition forms of Pakarena Dance, while the inner structure is the structure of values contained in Pakarena Dance.

Giddens makes clear that the definition of transformation as a physical change focusing on the transformation of dance structures is limited to the act of modifying preexisting structures [17]. While the internal structure referred by Levi-Strauss is clarified by the results of Andi Dwi Resqi Pramana's research which suggests that Buginese women are identical with the nature of malebbi', which means gentle and feminine behavior. Local culture has taught good things to the Bugis tribe women such as aesthetics, logic, and ethics contained in Pakarena Anida Dance. It becomes the guidance for Bugis women which is based on local values and the culture of the Bugis tribe. This research explains that Pakarena Anida Dance which is a reconstruction of the Classic Pakarena still upholds the values of local wisdom and culture of the Bugis tribe [18].
Table 1 Reconstruction Tables of Composition Forms

\begin{tabular}{|c|c|c|}
\hline \multirow{2}{*}{$\begin{array}{l}\text { Composi } \\
\text { tion Forms }\end{array}$} & \multicolumn{2}{|c|}{ Composition Form Reconstruction } \\
\hline & $\begin{array}{r}\text { Traditional } \\
\text { Pakarena Dance }\end{array}$ & $\begin{array}{r}\text { Pakarena } \\
\text { Anida } \text { Dance }\end{array}$ \\
\hline \multirow[t]{2}{*}{$\begin{array}{l}\text { Moveme } \\
\mathrm{nt}\end{array}$} & $\begin{array}{l}\text { Movements were } \\
\text { not well organized } \\
\text { (controlled by the front } \\
\text { dancers or Pauluang) }\end{array}$ & $\begin{array}{l}\text { Movements are } \\
\text { based on the four } \\
\text { compass directions } \\
\text { and clock-wise }\end{array}$ \\
\hline & $\begin{array}{l}\text { Movements were } \\
\text { repeated three times }\end{array}$ & $\begin{array}{l}\text { Movements are } \\
\text { repeated once }\end{array}$ \\
\hline $\begin{array}{l}\text { Dance } \\
\text { Variation }\end{array}$ & \begin{tabular}{lr}
\multicolumn{1}{c}{8} & variations \\
(Bunga & Karena, \\
Amme'lu, Ammempo, & Ammemon, \\
Tile, Alle'ko Bo'dong, & Bipas $\quad$ Ta'Sungke, \\
Sitaklei, Appalakkana)
\end{tabular} & $\begin{array}{l}6 \text { variations } \\
\text { (Ma'biring Kassi, } \\
\text { Sitaklei, Sonnayya, } \\
\text { Accarammeng, } \\
\text { Anging Kamalino, } \\
\text { Renjang-renjang) }\end{array}$ \\
\hline $\begin{array}{c}\text { Hand } \\
\text { Fan Position }\end{array}$ & $\begin{array}{l}\text { Hand fan covered } \\
\text { the dancers' face }\end{array}$ & $\begin{array}{l}\text { Hand fan no } \\
\text { longer covered the } \\
\text { dancers' face }\end{array}$ \\
\hline Singing & $\begin{array}{l}\text { Singing or royong } \\
\text { which was difficult to } \\
\text { follow }\end{array}$ & 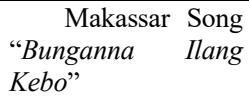 \\
\hline $\begin{array}{l}\text { Gendang } \\
\text { Beat }\end{array}$ & $\begin{array}{l}\text { Adjusted } \\
\text { follow the dancer's } \\
\text { movements }\end{array}$ & $\begin{array}{l}\text { Organized, } \\
\text { directed, and in tune } \\
\text { with the dancers' } \\
\text { movements }\end{array}$ \\
\hline Dancers & Royal members & $\begin{array}{l}\text { Common } \\
\text { people }\end{array}$ \\
\hline $\begin{array}{l}\text { Dance } \\
\text { Duration }\end{array}$ & All night long & $\begin{array}{c}9 \text { minutes } 18 \\
\text { seconds }\end{array}$ \\
\hline $\begin{array}{l}\text { Audienc } \\
\mathrm{e}\end{array}$ & $\begin{array}{l}\text { Members and } \\
\text { guests of the Kingdom } \\
\text { of Gowa }\end{array}$ & $\begin{array}{l}\text { Common } \\
\text { people }\end{array}$ \\
\hline $\begin{array}{l}\text { Floor } \\
\text { Pattern }\end{array}$ & $\begin{array}{l}\text { Monotonous with } \\
\text { leaders or Pauluang in } \\
\text { the front }\end{array}$ & \begin{tabular}{l}
\multicolumn{1}{c}{ Always } \\
improvised \\
modified
\end{tabular} \\
\hline
\end{tabular}

After the reconstruction phase carried out by Andi Nurhani Sapada (Anida), today people know Pakarena Dance by the name of Pakarena Anida Dance. Andi Nurhani Sapada brought Pakarena Dance from religious rituals to the performance stage to make it more accessible to audience seeking entertainment and beauty rather than spiritual values. Pakarena Dance has a very complicated music and dance genre that is still performed in the countryside and for the Makassar royal family for endless hours. Nurwahidah [19] stated that there were three stages in Traditional Pakarena Dance that would be danced all night; the first round was called Pakarena Samboritta, which was performed after Isha, the second round was called Pakarena Lantang Bangngia, performed at midnight, and the closing round was Pakarena Jangan Lea-Lea, performed when entering dawn. From Pakarena's original ritual dance, Andi Nurhani Sapada took some special movements and created a dance of less than ten minutes with very different accompaniment music. Sutton explained that Andi Nurhani Sapada began learning 
Pakarena Dance in 1951. He invited a group of famous expert dancers, Parancing, from the village of Polongbangkeng in Takalar, to his house. As he became more familiar with the repertoire of movements, accompaniment music, costumes, and patterns of interaction among dancers, he made radical changes to make them suitable for secular entertainment and diverse audience [20].

Based on observations and interviews, as well as literature studies, the writers found the reconstruction of Pakarena Dance as in Table 1. The reconstruction effort in the composition forms has main goals, which are expressing and relearning the dance regularly to preserve it by teaching it to students in Makassar, as well as adjusting the dance with the taste of the people of South Sulawesi.

\subsection{The Existence Of Pakarena Anida Dance In The Postmodern Era}

Freire \& Medeiros believe that folk dance is a way to recognize thousands of meanings, using culture as an expression tool, which is reading language and symbols as a way to express art [21]. It is rightly deserved that Indonesia's national culture assets are preserved; one of the ways to preserve is by holding a revitalization of Pakarena Dance by shifting the function and reconstructing the composition forms so that its existence is recognized in this postmodern era. Back then in the modern era, people glorified the originality and authenticity of an artwork, while in the postmodern era people are more likely to develop the existing art in a new pattern and scope. It aims to preserve a traditional artwork that must adjust to the changing times.

Idha Elbara (September 2019), an artist, art observer of South Sulawesi, and a lecturer at the Faculty of Arts and Design UNM, explained that Pakarena Anida Dance performance gave a great contribution to the culture of South Sulawesi, especially in the field of dance arts. The emergence of Pakarena Anida Dance brought the name of South Sulawesi for the first time at the National Palace during President Soekarno's administration. Suriati (September 2019), a teacher of Arts and Culture subject at SMAN 5 Pinrang, supported the existence of Pakarena Dance as a traditional dance taught at school. With the guidance of the cassettes published by $I K S$, Suriati claimed to teach Pakarena Anida Dance to students of SMAN 5 Pinrang since 2010 until now. The Pakarena Anida dance is usually performed at Indonesia's Independence Day's competitions, Pinrang Regency Anniversary competitions, honorary guest entertainments, wedding events, and annual school art performance.

Pakarena Dance is no longer only performed in Gowa or Makassar tribal circles, but also the Pakarena Anida Dance has been performed by many Bugis and Toraja tribes. People interested in Pakarena Anida Dance come from students aged 9-18 years old. The art gallery formed in Pinrang Regency called Lasinrang Art Studio makes Pakarena Anida Dance one of the traditional dances that must be taught to its members. A student community named "Community of Art (CoA)" at SMAN 5 Pinrang comprises all students and enthusiasts of arts at the school make Pakarena Anida Dance one of the traditional dances that must be performed at the annual school art performance.

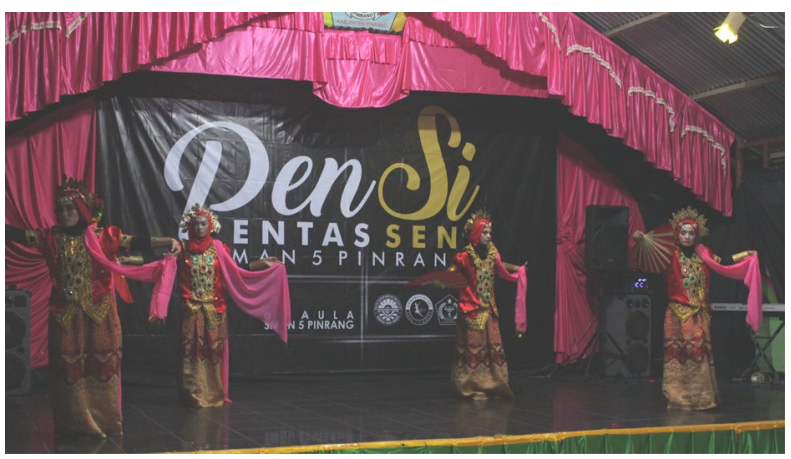

Figure 1 The Performance of Pakarena Anida Dance by the Community of Art (CoA) at SMAN 5 Pinrang (doc. Fawziah Magfirah, January 2019)

Pakarena Dance is now known in various walks of life in the form of Anida Pakarena Dance. Its existence in the world of dance is undoubtable. Even though it is classified as a difficult dance because it moves so slowly with hammering music and the use of played hand fan properties (open-close), it does not make Pakarena Dance devoid of interest. Conversely, with a high level of difficulty, Pakarena Anida Dance is a challenge to hone the ability and tenderness of the dancers' movements.

\section{CONCLUSION}

The Pakarena Dance explores the function shift from a ritual dance/ worship ceremony to a deity to a dance performance. The function shift occurred due to a change in beliefs from animism and dynamism to Islam, the propaganda of the traditional art renewal by the government, and a change in the mindset of postmodern society. Pakarena Dance was shown in the form of Performing Arts by South Sulawesi dance maestro, Andi Nurhani Sapada, resulting in the creation of Pakarena Anida Dance. Pakarena Dance was performed with patented movements and monotonous elements were removed out of it. Reconstruction of the composition forms of Pakarena Dance only occurs in the external structures such as movement variations, movement specifications, music, number of dancers, floor patterns, hand fan positions, and dance duration. The Pakarena Anida Dance is popular among South Sulawesi students 
because it is used as one of the traditional dances taught in the subject of Arts and Culture in high school, as well as a dance taught by the dance studio and art community in Pinrang Regency.

\section{REFERENCES}

1. SuharSuharto, Ben. "Tayub: pertunjukan dan ritus kesuburan. Masyarakat Seni Pertunjukan Indonesia [Tayub: performance and fertility rites. Indonesian Performing Arts Society]." 1999.

2. Sudarsono. "Seni pertunjukan Indonesia di era globalisasi [Indonesian performing arts in the era of globalization]." Gadjah mada University Press, 2002.

3. Hadi, Y. Sumandiyo. "Pasang Surut Tari Klasik Gaya Yogyakarta." PembentukanperkembanganMobilitas [It is the classical dance of Yogyakarta. "Development of mobility]." Yogyakarta: Lembaga Penelitian Institut Seni Indonesia (ISI) Yogyakarta (2001).

4. Sorokin, Pitirim. Contempory Sociological Theories. New York : Harper \& Row, 1928.

5. Jamilah, Jamilah, and Tony Mulumbot. "Makna Gerak dan Syair Dongang-Dongang Pakarena Anida di Sulawesi Selatan [The Meaning of Motion and Poetry of Dongang-Dongang Pakarena Anida in South Sulawesi]."Seminar Nasional Lembaga Penelitian UNM. Vol. 2. No. 1. 2017. URL :

https://ojs.unm.ac.id/semnaslemlit/article/view/399 6

6. Lathief, Halilintar, and Niniek Sumiani.

"Pakkarena: Sebuah Bentuk Tari Tradisi Makassar [Pakbecause: A form of Makassar tradition dance]." Pustaka Wisata Budaya. Jakarta: Proyek Pengembangan Media Kebudayaan, Departemen Pendidikan dan Kebudayaan (1995).

7. Sumaryono. Antropologi Tari dalam Perspektif Indonesia. Yogyakarta: Media Kreativa, 2017.

8. Wiwik, P Yusuf. Upacara tradisional Daerah Sulawesi Selatan. Departemen Pendidikan dan Kebudayaan, Sulawesi Selatan, 1992. Unpublished

9. Jamilah. "Struktur dan Fungsi Pakarena Anida di Sulawesi Selatan [Structure and function of Pakarena Anida in South Sulawesi]". Tesis, Program Pascasarjana ISI Yogyakarta, Yogyakarta, 2002. Unpublished

10. Soekanto, Soerjono. "Sosiologi Suatu Pengantar. (cetakan ke-44) ["The Sociology of an introduction (The 44 mold)]." Jakarta: PT Raja Grafindo Persada (2012).

11. Soedarsono, R. M. "Tari-tarian Indonesia I [Taritarian Indonesia I [Indonesian dance].” Jakarta: Proyek Pengembangan Media Kebudayaan Direktorat Jendral Kebudayaan, Departemen Pendidikan dan Kebudayaan, 1977." Pengantar dan Komposisi Tari.

12. Anggrawansyah, Syaharuddin. "Pakarena di Sulawesi Selatan: Dari tarian tradisional ke neotradisonal [Pakarena in South Sulawesi: from traditional to neo-tradisonal dances]"Anggrawansyah Syaharuddin. Diss. University of Malaya, 2017. URL : http://studentsrepo.um.edu.my/id/eprint/7504

13. Wolf, Janet. The Social Production of Art. New York : New York University Press, Second Edition, 1993.
14. Lauer, Robert H. "Perspektif tentang perubahan sosial [Perspectives on Social Change]." Jakarta: Rineka Cipta (1993).

15. Benny, H. Hoed. "Semiotik dan Dinamika Sosial Budaya [Semiotics and social and cultural dynamics]." Jakarta: Komunitas Bambu (2011).

16. Piliang, Yasraf Amir. "Sebuah dunia yang dilipat: realitas kebudayaan menjelang milenium ketiga dan matinya posmodernisme [A world folded: cultural realities leading up to the third millennium and the death of Posmodernism]". Mizan Pustaka, 1998.

17. Giddens, Anthony. "Teori Strukturasi : Dasar-dasar Pembentukan Struktur Sosial Masyarakat [Structuration theory: The Fundamentals of Community social structure formation]." Yogyakarta : Pustaka Pelajar, 2011.

18. Pramana, Andi Dwi Resqi, and Trianti Nugrahaeni. "Pakarena Anida Dance as Guidance Values of Buginese Women in Indonesia [Pakarena Anida Dance as Guidance Values of Buginese Women in Indonesia]." International Conference on Arts and Design Education (ICADE 2018). Atlantis Press, 2019. DOI: https: //doi.org/10.2991/icade18.2019 .60

19. Sutton, R. Anderson. "Tradition serving modernity? The musical lives of a makassarese drummer." Asian music 37.1 (2006): 1-23. URL: https://www.jstor.org/stable/4098486

20. Freire, Isabel Batista, and R. M. N. Medeiros. "King, Queen, Dama de Paco and Orixas: Sense and Meanings of the Characters and Symbols who Dance." HOLOS 5 (2014): 32-43. DOI: 10.15628/holos.2014.2552

[21] Nurwahidah. 2018. "Pakarena Sambori'na dalam Etnis Makassar [ Pakarena Sambori'na in Makassar Ethnicity]". Gowa: Pusaka Almaida. Unpublised 